\title{
Biostratigraphical zonation and correlation of five Late Cretaceous - Tertiary wells, offshore central West Greenland
}

\author{
Bruno B. Toxwenius
}

During 1976 and 1977, five exploratory wells were drilled offshore central West Greenland, between $65^{\circ}$ and $68^{\circ} \mathrm{N}$ (figs 1 and 2) (Henderson et al., 1981). The Geological Survey of Greenland (GGU) received samples from all the wells, comprising 2228 composite cutting samples ( $10 \mathrm{~m}$ interval), 456 sidewall cores, $30 \mathrm{~m}$ conventional core and 3276 samples of varied provenance. From this material, two independent biostratigraphical analyses on 1000 ditch cutting samples and 65 sidewall cores were performed within GGU. One survey was based on palynomorphs (Croxton, 1981 and internal reports), the other, by the author, was based on foraminifera and larger diatoms.

In addition to GGU's investgations, 14 reports concerning the micropalaeontology and biostratigraphy of the five wells were prepared by exploration companies and consultants on the basis of foraminifera, palynomorphs (identifications by, inter alia J. M. Hansen and L. I. Costa), diatoms, radiolarians and calcareous/siliceous nannoplankton (identifications by, inter alia K. Perch-Nielsen). This constitutes the total amount of accessible biostratigraphical data from the offshore part of the West Greenland Basin; it comprises more than 8000 analysed samples. Compilation of the biostratigraphical data from these sources, allows a fairly detailed stratigraphical correlation and understanding of the five wells (Toxwenius, 1986). In this paper a summary of the stratigraphy and successive correlation of the five wells is presented. The lithostratigraphy and sedimentology of the wells have been reported by Rolle (1985).

\section{Planktonic stratigrahpical zonations and correlation of the five wells}

Occurrences of stratigraphically important and cosmopolitan fossil taxa can be referred to the commonly used plankton stratigraphic zonations. Some of these zones and the positions of the consequently inferred epoch boundaries in the five wells are shown on the correlation chart (fig. 3). Some of the diagnostic fossil taxa typical of these zones, are given below.

Dinoflagellate occurrences are referred to the K and D zonations of Lucy I. Costa (personal communication, 1982), supported by Williams \& Bujak (1985). Occurrences of calcareous nannoplankton are referred to the NP and NN zonations of Martini (1971) with revisions by Aubry (1985) and Perch-Nielsen (1985). Planktonic foraminifera are referred to the $\mathrm{P}$ and $\mathrm{N}$ zonations of Banner \& Blow (1965), Blow (1969) and Berggren \& van Couvering (1974), with revisions by Bolli \& Saunders (1985) and Toumarkine \& Luterbacher (1985).

Campanian. Zone K3. The Campanian sequence, zone $\mathrm{K} 3$, is recognised by the highest occurrence of the dinocyst taxa Chatangiella tripartita, Paleohystrichophora infusorioides, Laciniadinium arcticum, Spinidinium echinoideum and Chatangiella ditissima. A Late Cretaceous age is also indicated by the highest occurrence of Aquilapollenites and Diatom E (Given \& Wall, 1971) in this sequence. 
Fig. 1. Location of selected exploratory wells and land sections through Mesozoic - Cenozoic strata of the Labrador Sea - Baffin Bay area. H $=$ Hellefisk $1 ; \mathbf{I}=$ Ikermiut $1 ; \mathrm{K}=$ Kângamiut 1; N2 = Nukik 2; N1 = Nukik 1. Compiled from Gradstein \& Srivastava (1980).

OUTCROPS OF MESOZOIC

AND CENOZOIC SEDIMENTS (ONSHORE)

tertiary basalts

(ONSHORE)

$\odot$ DEEP WELL

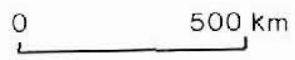

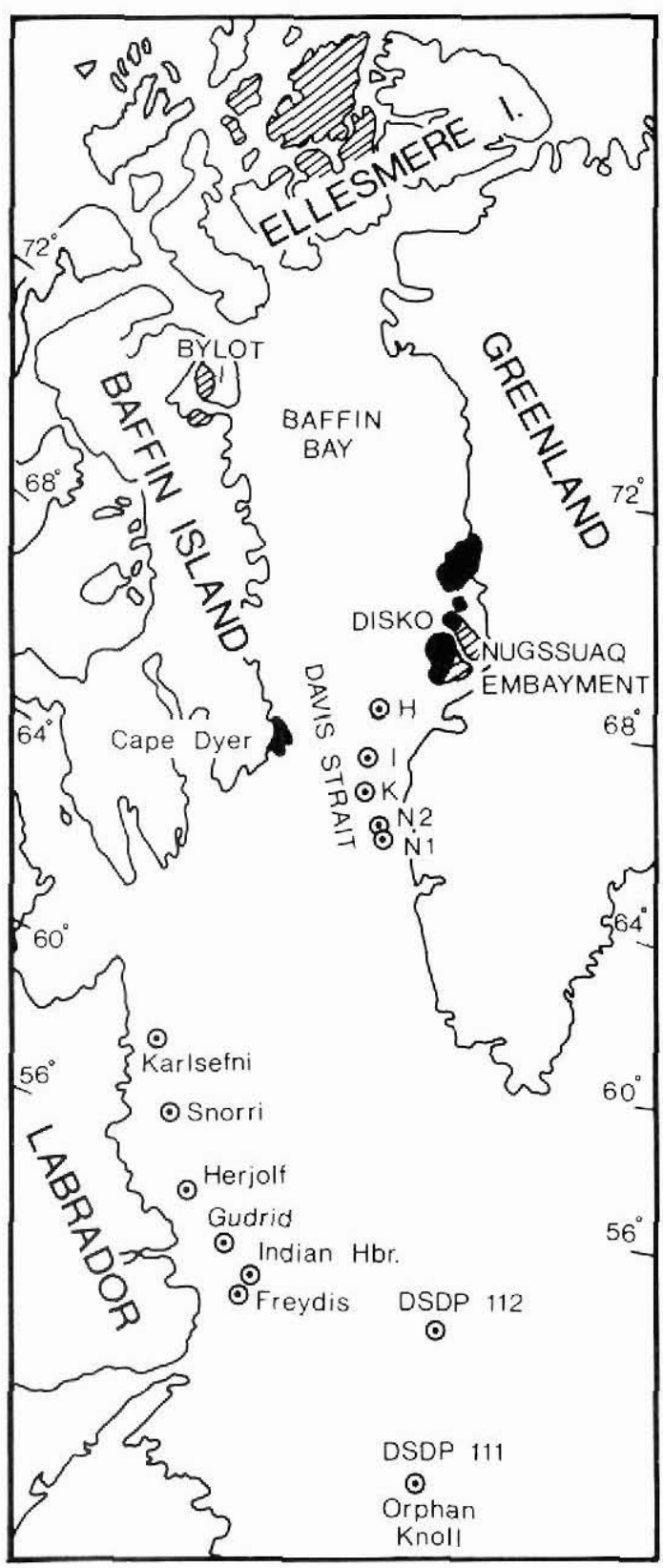

Maastrichtian-Danian? Zones K2 to D2. It is possible that a thin sequence of MaastrichtianEarly Paleocene age is present in the Ikermiut 1 well. This age is inferred from the occurrence of a mixed assemblage of dinoflagellate taxa, in the uppermost part of zone K3 mentioned above and the lowermost part of zone D3 (see below). The assemblage consists of 


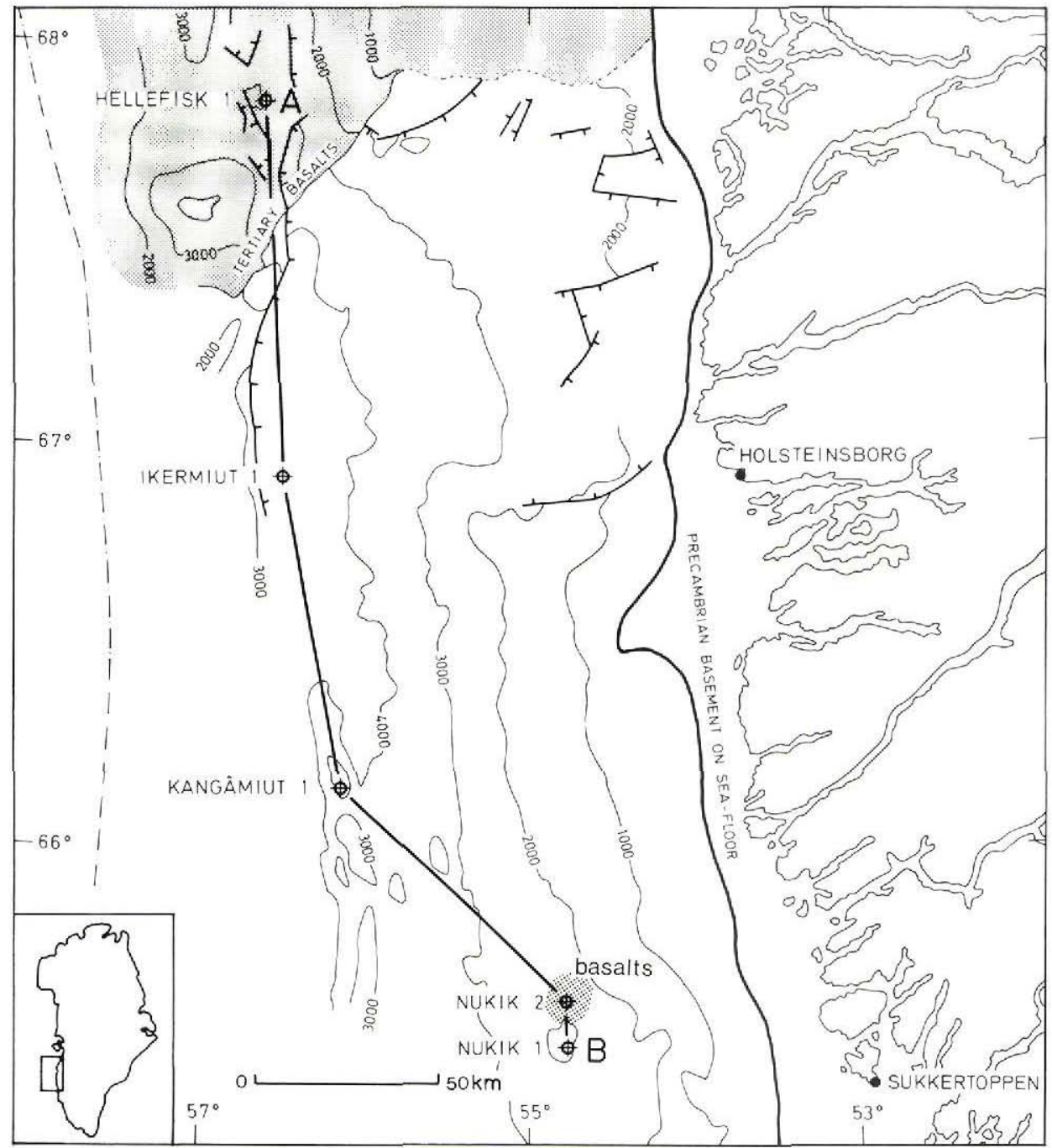

Fig. 2. Location of the five exploratory wells offshore central West Greenland. Contours in milliseconds of two-way travel time show the depth to Precambrian basement and depth to surface of Tertiary basalts. Modified from Henderson et al. (1981).

Odontochitina operculata, Chatangiella victoriensis, Xenascus ceratioides, Palynodinium grallator, Cannosphaeropsis sp., Ceratiopsis diebelii, Alisocysta reticulata and Eisenackia crassitabulata - indicative of zones K2 to D2.

Middle Paleocene. Zone D3 and zone NP 4/5. The Middle Paleocene sequence, zone D3, is characterised by the occurrence of the alga Palambages morulosa concurrent with the dinoflagellate taxa Ceratiopsis striata, Paleocystodinium australinum, Ceratiopsis speciosa and 
Thalassiphora delicata. A Middle Paleocene age, corresponding to zones NP 4/5, is also inferred by the concurrent occurrence of the calcareous nannofossils Chiasmolithus danicus, Chiasmolithus bidens, Neochiastozygus modestus, Neochiastozygus saepes and Toweius eminens.

Late Paleocene. Zones D4, D5 and zone P5. The beginning of the Late Paleocene sequence, zone D4, is identified by the co-occurrence of the dinoflagellates Eisenackia crassitabulata, Ceratiopsis dartmooria, Achomosphaera alcicornu, Spiniferites cornutus and Alisocysta margarita. The top of the Late Paleocene sequence, corresponding to zone D5, is recognised by the concurrent occurrence of the dinoflagellates Apectodinium summissum, Apectodinium parvum, Apectodinium augustum, Paleoperidinium pyrophorum and Homotryblium tenuispinosum. A Late Paleocene age of this inverval is also indicated by the highest occurrence of the planktonic foraminifera Globigerina triloculinoides, concurrent with Pseudohastigerina wilcoxensis and Globigerina linaperta, corresponding to zone P5.

Early Eocene. Zones D6, D9 and zone P9. The base of the Early Eocene sequence, corresponding to zone D6, is recognised by the concurrent occurrence of the dinoflagellate taxa Muratodinium fimbriatum, Ceratiopsis speciosa, Wetzeliella astra, Kisselovia crassiramosa, Wetzeliella meckelfeldensis and Deflandrea phosphoritica. The top of the Early Eocene sequence, zone D9, is recognised by the concurrent occurrence of the dinocysts Eatonicysta ursulae, Glaphyrocysta vicina, Dracodinium varielongitudum, Wilsonidium tabulatum, Phthanoperidinium comatum and Areosphaeridium diktyoplokus. A late Early Eocene age is also inferred by the concurrent occurrence of the planktonic foraminifera Acarinina intermedial Acarinina wilcoxensis, Pseudohastigerina micra, Truncorotaloides collactea and Globigerina eocaena; species indicative of zone P9.

Middle Eocene - Late Eocene. Zones D10, D12. The base of the Middle Eocene sequence is recognised by the lowermost occurrence of the dinoflagellate Cordosphaeridium cantharellum, indicating zone D10. The top of the Late Eocene, corresponding to D12, is recognised by the uppermost occurrence of the dinocysts Phthanoperidinium echinatum, Glaphyrocysta ordinata and Wetzeliella lunaris.

Early Oligocene. Zone D13 and zone NP21. The base of the Early Oligocene, zone D13, is recognised by the concurrent occurrence of the dinocysts Cribroperidinium tenuitabulatum and Kisselovia coleothrypta. An Early Oligocene age is also inferred by the uppermost occurrence of the calcareous nannofossil Ericsonia subdisticha, indicating zone NP21.

Early Oligocene and Early Miocene. Mixed interval of zones NP21-NP22 and NN1-NN4. Between the base of the Early Oligocene and the top of the Early Miocene sequence, an interval occurs with a mixed microfossil assemblage of Early Oligocene and Early Miocene age, including the dinoflagellates Cordosphaeridium fibrospinosum, Wetzeliella symmetrica and Cordosphaeridium cantharellum, the planktonic foraminifera Globigerinita naparimaensis, Globigerina praebulloides leroyi and Globigerina euapertura and the calcareous nannofossils Discoaster variabilis, Helicosphaera recta, Dictyococcites bisectus, Isthmolithus recurvus, Ericsonia formosa and Chiasmolithus oamaruensis. The concurrent occurrence of these microfossils suggests that the taxa of zones NN1-NN4 (Early Miocene) are mixed with taxa of 
zones NP21-NP22 (Early Oligocene). No microfossil taxa of unambiguous Late Oligocene age have been found.

Early Miocene. Zone D16. The top of the Early Miocene, zone D16, is indicated by the uppermost occurrence of the dinoflagellate Cordosphaeridium cantharellum.

Late Miocene. Zone D20. The top of the Late Miocene sequence is characterised by the uppermost occurrence of the dinoflagellate Operculodinium centrocarpum suggesting zone D20 (Barss et al., 1979).

Early Pliocene. Zones N18-N19. The base of the Early Pliocene is recognised by the occurrence of the tropical-subtropical planktonic foraminifera Globorotalia acostaensis, Globorotalia tumida, Globigerinoides conglobatus, Globigerina praebulloides, Orbulina universa and Globigerina venezuelana, which place the sequence in zones N18-N19.

\section{Biostratigraphical assemblages - correlation with Labrador shelf}

The successions and assemblages of microfossils within the five wells are basically identical to those described from the Labrador shelf wells. For instance, Dufaure et al. (1976) described a succession of mainly foraminifera, larger diatoms and calcareous nannoplankton from which a number of stratigraphic units ranging from Campanian to Pliocene were recognised. The same succession of foraminifera, larger diatoms and calcareous nannoplankton is encountered in the five wells from the central West Greenland shelf; consequently the same stratigraphic units (epochs) can be recognised (fig. 3).

Gradstein \& Agterberg (1982) proposed eight informal biostratigraphical assemblages, based on the stratigraphic distribution of mainly foraminifera and larger diatoms in the Labrador shelf wells. These assemblages were assigned provisional ages. Seven of these eight Labrador assemblages have been recognised in the five West Greenland wells (Toxwenius, 1986).

Barss et al. (1979) proposed twelve informal biostratigraphic assemblages, based on the stratigraphic distribution of palynomorphs in the Labrador shelf wells. These assemblages were also assigned provisional ages. Ten of these twelve palynomorph assemblages from the Labrador shelf have been recognised in the five West Greenland wells (Croxton, 1981; Toxwenius, 1986).

\section{Conclusions}

The stratigraphical summary (fig. 3) provides new information about the geological history of the West Greenland Basin and of the Davis Strait region. Five of the main conclusions are given below.

1. In the Ikermiut 1 well, the floral and faunal characteristics of the lower shale sequence (Ikermiut Formation of Rolle, 1985), do not exclude continuous sedimentation across the Mesozoic - Tertiary boundary. If there is a Maastrichtian - Danian sequence it is very thin $(\max .80 \mathrm{~m})$. 


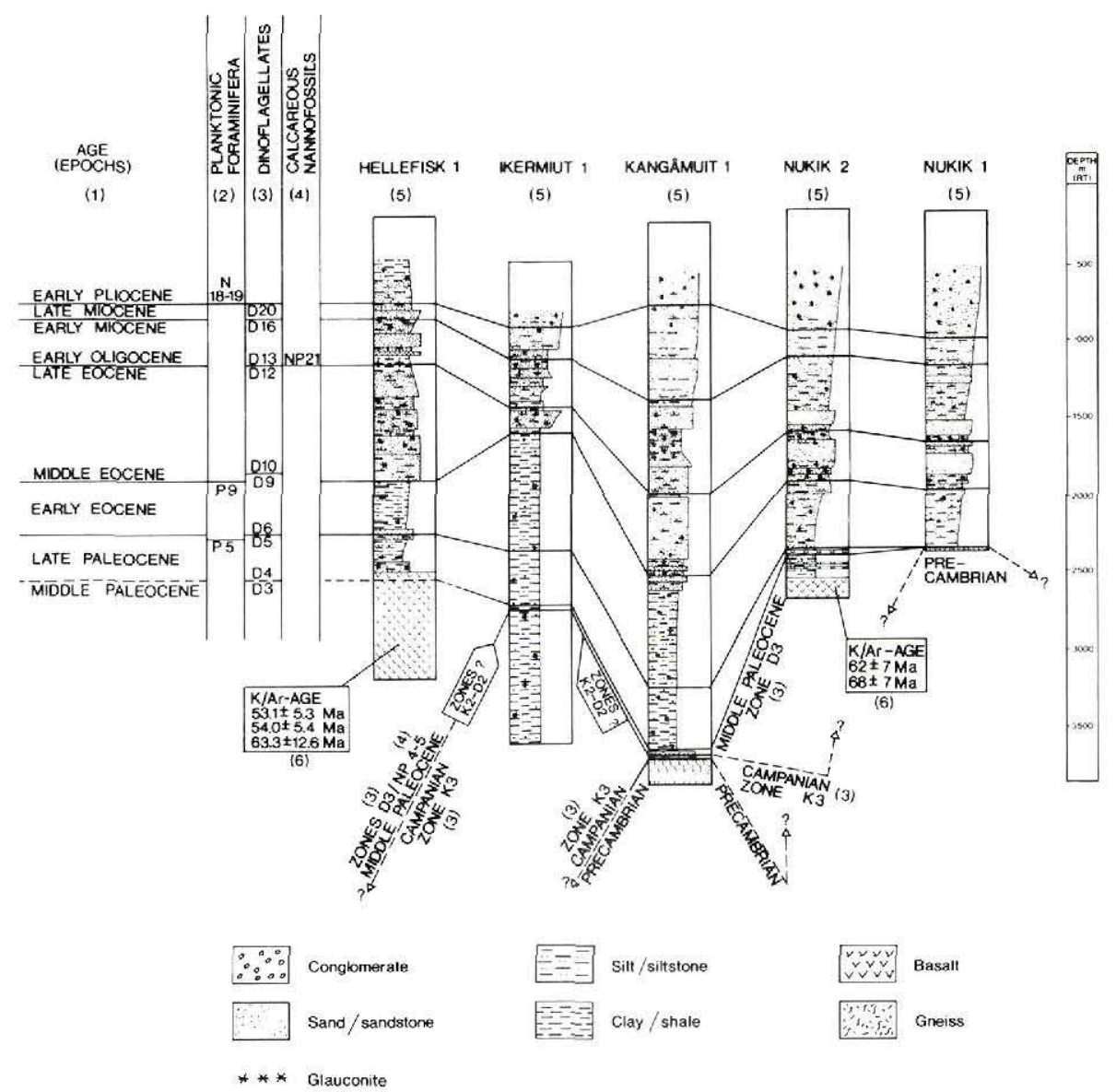

Fig. 3. Summary of biostratigraphical zonation and correlation of the five exploratory wells, offshore central West Greenland.

(1) Correlation of planktic stratigraphical zones with ages. Aubry (1985), Berggren et al. (in press) and Bolli et al. (1985). (2) Planktonic foraminiferal zonation. Banner \& Blow (1965), Blow (1969) and Berggren \& van Couvering (1974). (3) Dinoflagellate zonation. L. I. Costa (personal communication, 1982). (4) Calcareous nannoplankton zonation. Martini (1971). (5) General lithology. Rolle (1985). (6) K/Ar dating of basalts. N. Hald and J. G. Larsen (personal communication, 1985).

2. The subaerial tholeiitic basalts encountered in the Hellefisk 1 well (N. Hald \& J. G. Larsen, personal communication, 1985) are believed to form the seaward extension of the onshore basalts of Disko (Henderson et al., 1981). Thus the Late Paleocene age of the overlying sediments suggests that the tholeiitic part of the West Greenland Basalt Group (Hald \& Pedersen, 1975) continued into the Late Paleocene. This conclusion is in agreement with the K/Ar age of the basalts of the Hellefisk 1 well, $53.1 \pm 5.3 \mathrm{Ma}, 54.0 \pm 5.4 \mathrm{Ma}$ and $63.3 \pm$ 12.6 Ma (N. Hald and J. G. Larsen, personal communication, 1985), i.e. Late Paleocene Middle Eocene on the time scale of Berggren et al. (in press), and with the data from the onshore area (Beckinsale et al., 1974; Parrot \& Reynolds, 1975). 
3. At the Early Eocene - Middle Eocene boundary a conspicuous change in the sedimentary environment occurs (Rolle, 1985). In the Kângamiut 1 well this is reflected in the change from dark grey, carbonaceous, pyritic, organic-rich, fairly deep marine (c. $200 \mathrm{~m})$, transgressive mud-shale (Ikermiut Formation, Rolle, 1985) to strongly prograding, shallowmarine, high-energy, medium grained sand bodies (Kângamiut Formation, Rolle, 1985) (fig. 3). This may be related to the relative changes in coastal onlap, or global sea-level drop, at the Early Eocene - Middle Eocene boundary as outlined by e.g. Vail \& Hardenbol (1979).

4. No fossil taxa of unambiguous Late Oligocene age have been found. In all wells an interval occurs with a mixed microfossil assemblage of Early Oligocene and Early Miocene age. This suggests that there is a hiatus corresponding to at least the Late Oligocene. This hiatus could be compared to the hiatuses in the nearest wells on the Labrador shelf, i.e. Karlsefni A-13 (Oligocene), Snorri J-90 (Late Oligocene) and Herjolf M-92 (Oligocene) (fig. 1) (Barss et al. 1979). It can possibly be related to the major relative change in coastal onlap, or global sea-level drop, at the Early Oligocene - Late Oligocene boundary as outlined by e.g. Vail \& Hardenbol (1979), see also Aubry (1985).

5. The appearance of warm water planktonic foraminifera in the Early Pliocene, points to the incursion of warm water masses along the coast of central West Greenland in Early Pliocene time. This may be the same event as seen in the Indian Harbour well on the Labrador shelf and in the wells of DSDP Sites 111 and 112 (fig. 1). This supports the idea that the surface flow from the Arctic toward the Atlantic, through the Labrador passage, did not become fully established until after Early Pliocene time (Gradstein \& Srivastava, 1980).

Acknowledgements. The author is grateful to K. Perch-Nielsen, L. I. Costa, J. M. Hansen and C. A. Croxton for the use of their unpublished data on the occurrences of the calcareous nannofossils and the palynomorphs.

\section{References}

Aubry, M.-P. 1985: Northwestern European Paleogene magnetostratigraphy, biostratigraphy, and paleogeography: calcareous nannofossil evidence. Geology 13, 198-202.

Banner, F. T. \& Blow, W. H. 1965: Progress in the planktonic foraminiferal biostratigraphy of the Neogene. Nature, Lond. 208, 1164-1166.

Barss, M. S., Bujak, J. P. \& Williams, G. L. 1979: Palynological zonation and correlation of sixty-seven wells, eastern Canada. Pap. geol. Surv. Can. 78-24, 1-118.

Beckinsale, R. D., Thompson, R. N. \& Durham, J. J. 1974: Petrogenetic significance of initial ${ }^{85} \mathrm{Sr} /{ }^{86} \mathrm{Sr}$ ratios in the North Atlantic Tertiary Igneous Province in the light of $\mathrm{Rb}-\mathrm{Sr}, \mathrm{K}-\mathrm{Ar}$ and ${ }^{18} \mathrm{O}$-abundance studies of Sarqâta qáqâ Intrusive Complex, Ubekendt Ejland, West Greenland. J. Petrol. 15, 525538.

Berggren, W. A. \& Van Couvering, J. A. 1974: The Late Neogene. Biostratigraphy, geochronology and paleoclimatology of the last 15 million years in marine and continental sequences. Palaeogeogr. Palaeoclimatol. Palaeoecol. 16, 1-215.

Berggren, W. A., Kent, D. V. \& Flynn, J. J. in press: Paleogene geochronology and chronostratigraphy. In Snelling, N. J. (edit.) Geochronology and the geological record. Spec. Pap. Geol. Soc. Lond. 
Blow, W. H. 1969: Late Middle Eocene to Recent planktonic foraminiferal biostratigraphy. Proceedings First International Conference on Planktonic Microfossils, Geneva 1967, 1, 199-422.

Bolli, H. M. \& Saunders, J. B. 1985: Oligocene to Holocene low latitude planktic foraminifera. In Bolli, H. M., Saunders, J. B. \& Perch-Nielsen, K. (edit.) Plankton stratigraphy, 155-262. Cambridge: University Press.

Bolli, H. M., Saunders, J. B. \& Perch-Nielsen, K. 1985: Comparison of zonal schemes for different fossil groups. In Bolli, H. M., Saunders, J. B. \& Perch-Nielsen, K. (edit.) Plankton stratigraphy, 3-10. Cambridge: University Press.

Croxton, C. A. 1981: Palynostratigraphy offshore West Greenland. Unpubl. intern. GGU rep., 26 pp.

Dufaure, P., McWhae, R. \& Verdenius, J. G. 1976: Tertiary and Upper Cretaceous in offshore Labrador boreholes; first stratigraphical results. In Symp. Benthonic Foraminifera, Halifax 1975. Spec. Publ. Marit. Sed. 1B, 509-522.

Given, M. M. \& Wall, T. H. 1971: Microfauna from the upper Cretaceous Bearpaw formation of southcentral Alberta. Bull. Can. Petrol. Geol. 19, 504-546.

Gradstein, F. M. \& Agterberg, F. P. 1982: Models of Cenozoic foraminiferal stratigraphy - Northwestern Atlantic margin. Proc. Quantitative Stratigraphic Correlation, Symp. 16th Int. Geol. Congr., Paris, 1980, 119-170. London: Wiley \& Sons.

Gradstein, F. M. \& Srivastava, S. P. 1980: Aspects of Cenozoic stratigraphy and paleoceanography of the Labrador Sea and Baffin Bay. Palaeogeogr. Palaeoclimatol. Palaeoecol. 30, 261-295.

Hald, N. \& Pedersen, A. K. 1975: Lithostratigraphy of the Early Tertiary volcanic rocks of central West Greenland. Rapp. Grønlands geol. Unders. 69, 17-24.

Henderson, G., Schiener, E. J., Risum, J. B., Croxton, C. A. \& Andersen, B. B. 1981: The West Greenland basin. In Kerr. J. Wm. \& Fergusson, A. J. (edit.) Geology of the North Atlantic borderlands. Mem. Can. Soc. Petrol. Geol. 7, 399-428.

Martini, E. 1971: Standard Tertiary and Quaternary calcareous nannoplankton zonation. In Farinacci, A. (edit.) Proceedings II Planktonic Conference, Roma 1970. Tecnoscienca 2, 739-785.

Parrott, R. J. E. \& Reynolds, P. H. 1975: Argon-40/Argon-39 geochronology: age determinations of basalts from the Labrador Sea area. Abstr. Geol. Soc. Am. 7, 835 only.

Perch-Nielsen, K. 1985: Cenozoic calcareous nannofossils. In Bolli, H. M., Saunders, J. B. \& PerchNielsen, K. (edit.) Plankton stratigraphy, 427-554. Cambridge: University Press.

Rolle, R. 1985: Late Cretaceous - Tertiary sediments offshore central West Greenland: lithostratigraphy, sedimentary evolution, and petroleum potential. Can. J. Earth Sci. 22, 1001-1019.

Toumarkine, M. \& Luterbacher, H. 1985: Paleocene and Eocene planktic foraminifera. In Bolli, H. M., Saunders, J. B. \& Perch-Nielsen, K. (edit.) Plankton stratigraphy, 87-154. Cambridge: University Press.

Toxwenius, B. B. 1986: Compilation of Late Cretaceous - Tertiary biostratigraphic data and correlation of five wells, offshore central West Greenland. Unpublished. Grønlands geol. Unders. Open file report.

Vail, P. R. \& Hardenbol, J. 1979: Sea level changes during the Tertiary. Oceanus 22, 71-79.

Williams, G. L. \& Bujak, J. P. 1985: Mesozoic and Cenozoic dinoflagellates. In Bolli, H. M., Saunders, J. B. \& Perch-Nielsen, K. (edit.) Plankton stratigraphy, 847-964. Cambridge: University Press. 